J. Product. \& Dev., 16(3):321-344(2011)

\title{
RESPONSE OF ONION CROP TO DIFFERENT NITROGEN SOURCES AND POTASSIUM APPLICATION METHODS
}

\author{
Wafaa A. Fekry \\ Plant Production Department, Efficient Productivity Institute, Zagazig \\ Univeristy, Egypt.
}

\section{ABSTRACT}

This investigation was carried out during two successive winter seasons of 2007 / 2008 and 2008/ 2009 at Moshtohor Experimental Farm , Faculty of Agriculture, Benha University to study the effect of applying different nitrogen sources at the recommended dose of $N$, i.e., mineral nitrogen (ammonium sulphate) and organic nitrogen (biogas manure) and their combination as well as two potassium fertilizers in the form of potassium sulphate as soil addition and potassium oxide as foliar application, either single or in combination with others or with nitrogen sources on plant growth, yield and its components, as well as chemical constituents of onion plant parts (Allium cepa L.) cv. Giza-20.

Obtained results indicated that, using nitrogen fertilizer in the form of $50 \%$ mineral $-N+50 \%$ organic $-N$ recorded maximum values of plant growth characters, expressed as plant height, number of leaves/plant, fresh and dry weight of leaves and bulbs, plant fresh and dry weight, neck and bulb diameter, bulbing ratio, percentage of total $N, P$ and $K$ in leaves and bulbs, bulb yield and its components i.e., average bulb weight, total, marketable and exportable yield. It increased the nutritive value of bulb expressed as N, P, K and T.S.S. percentage compared to the other tested treatments.

Application of potassium as $24 \quad \mathrm{~kg} \quad \mathrm{~K}_{2} \mathrm{O} / \mathrm{fed}$ as(potassium sulphate)as soil application plus $2 \%$ potassium oxide as foliar application being the best treatment which led to the vigor plant growth, higher minerals content of leaves and bulbs, heaviest bulb yield and the best physical and chemical proprieties of bulbs.

It could be concluded that using 50\% mineral- $N+50 \%$ organic- $N$ in combination with $24 \mathrm{~kg} \mathrm{~K}$ O/fed as soil application $+2 \%$ potassium oxide as foliar spray proved to be the most effective treatment to obtain vigor plant growth, highest total, exportable (grade land 2)and marketable(grade 1,2and 3) of yield/feddan and the best quality of onion bulbs as well as lowering cost production and it may be a way to reduce the environmental pollution.

Key words: Onion crop, nitrogen sources, potassium, application methods 


\section{INTRODUCTION}

Onion (Allium cepa L.) is one of the most important vegetable crops. It is grown at a large scale either for local consumption or exportation to Europe and Arab countries, since it is one of the source for hard currency, due to the early availability of the crop for foreign markets as well as, its higher quality which known by their high total soluble solids (TSS) content and high pungency. That is why it is very long-keepers. The highest productivity of onion crop with best quality can be achieved through increasing the cultivated area and application of the best agricultural practices for onion production.

In this respect fertilizers type and method of application judge the productivity of onion yield. Both organic and inorganic nitrogen fertilizers as well as potassium fertilizers were proved to be very essential for the production of higher yield with best quality. Nitrogen is an essential element required for plant growth which tended to encourage cell division and elongation that reflected an increase of plant length and number of leaves per plant. Moreover, $\mathrm{N}$ is essential for synthesis the amino acids, protein and nucleic acids compounds that have a vital role in plant metabolism (Mayer and Anderson, 1952 and Devlin, 1969).

Furthermore, supplying onion plants with $\mathrm{N}$ - fertilizer was proved by many studies to be of great importance on the rate of metabolic processes for producing high economical yield with good quality. Some of these studies revealed that increasing the level of mineral nitrogen fertilizer has an important role for enhancing growth rate and promoted bulbs yield production and its quality (Mahmoud, 2006, Ibraheim,2010, Fekry and Abou El- Salehein, 2010, Abd El-Samad et al., 2011 and Abdissa et al., 2011) on onion.

The excessive application of chemical fertilizers led to increasing production cost. The residual of mineral fertilizers has seriously effect on the quality of agricultural products and people's health, caused environmental pollution. Therefore, a great interest has been generated to apply organic and inorganic addition to establishment a good ecoenvironment.

Organic manure contains higher levels of relatively available nutrient elements, which are essentially required for plant growth and serves as a good natural soil texture conditioner being rich in organic matter (Mahmoud, 2006, Abou El- Salehein et al., 2008, Ibraheim, 2010, Fekry and Abou El- Salehein, 2010, on onion and El-Zohery, 2003 on garlic).

Although potassium is not a constituent of any organic molecule or plant structure, it is involved in numerous biochemical and physiological processes such as stomatal regulation of transpiration and photosynthesis. Potassium is also involved in photophosphorylation, transportation of photoassimilates from source tissue via the phloem to sink tissues, enzyme 
activation, turgor maintenance and stress tolerance. Potassium also provides resistance against pest and diseases (Marschner, 1995).

Even though, potassium is abundant in many soils, the bulk of soil potassium may be unavailable to plants because the pool of plant available $\mathrm{K}$ is much smaller compared to the other forms of K. Potassium exists in several forms in the soil and plants can only directly take-up solution $\mathrm{K}$ (Tisdale et al., 1985). Potassium uptake by plants from the soil solution is regulated by several plant factors (i.e., genetics and development stage) and numerous environmental factors, including soil properties and adequate moisture (Brady and Weil, 1990).

This view regarding how we can need to benefit from different potassium fertilization modes (e.g. soil vs., foliar fertilization or hydroponic applied) and differences in sources of $\mathrm{K}$ fertilizer.

There are some problems which prevent the onion plants from using sufficient amounts of potassium to obtain high productivity, such as potassium ions adsorbed by clay minerals in the clay soils and/or interlayer of minerals (Graham and Lopez, 1969).

In this respect, such soil fertilization problems can be solved by foliar fertilizer application. Also, foliar fertilization is more economical than root application due to the higher degree of applied nutrients utilization and the continuous increases in the costs of using chemical fertilizers, which makes the nutrients more efficient (Alexander, 1986 and El-Morsy et al., 2004).

Several investigators reported that onion plants growth, yield and its components and quality were generally markedly advanced by potassium fertilization ( El-Bassiony, 2006, Ghoname et al., 2007, Abou El- Salehein et al., 2008 and Abd El-Al et al., 2010).

With regard to the effect of interaction between nitrogen and potassium fertilizers, several investigators indicated that such combination enhanced plant growth, stimulated dry matter accumulation and increased bulb yield and quality ( El-Oksh et al., 2002, El-Beheidi et al., 2004 and Ibraheim, 2010) on onion.

On the other hand, supplying vegetable crops with organic and inorganic fertilizers were proved to be very essential for the production of higher yield and for improving its quality (Mengel and Kirkby 1978, Mahmoud, 2006 and Ibraheim, 2010 on onion and El-Zohery, 2003 on garlic).

Therefore, the object of this work was to study the effect of different $\mathrm{N}$ sources, i.e., organic (biogas manure) and inorganic (Ammonium sulphate 20.5 $\% \mathrm{~N}$ ) and their combination, as well as K-sources, i.e., potassium sulphate (48 $\left.\% \mathrm{~K}_{2} \mathrm{O}\right)$ and potassium oxide $\left(36.5 \% \mathrm{~K}_{2} \mathrm{O}\right)$ with $\mathrm{K}$-application methods (soil or foliar application) on growth, yield, and chemical composition of the onion plants. 


\section{MATERIALS AND METHODS}

This investigation was carried out during the two successive winter seasons of 2007/2008 and 2008/2009 at Moshtohor Experimental Farm , Faculty of Agriculture, Banha University, Kalubia Governorate to study the effect of organic (biogas manure) and inorganic nitrogen fertilizer (Ammonium sulphate $20.5 \%$ ) each of them solely or as a mixture form combined with sources of potassium fertilizers, i.e., potassium sulphate $\left(48 \% \mathrm{~K}_{2} \mathrm{O}\right)$ applied as soil addition and potassium oxide $\left(36.5 \% \mathrm{~K}_{2} \mathrm{O}\right)$ added as foliar application on vegetative growth, chemical composition of plant foliage, yield and its components as well as bulb quality of onion plants (Allium cepa L.)cv. Giza 20.

The physical and chemical properties of the experimental soil field were determined according to Black (1982) and are shown in Table 1. The chemical analyses of tested organic manure was done according to the methods described in (A.O.A.C., 1990) and are tabulated in Table 2.

Table 1: Mechanical and chemical analysis of the experimental soil as average during the two seasons of study.

\begin{tabular}{lc}
\hline Soil characteristics & values \\
\hline Mechanical analysis & \\
Coarse sand (\%) & 8.1 \\
Fine sand (\%) & 17.0 \\
Silt (\%) & 34.4 \\
Clay (\%) & 40.5 \\
Texture class & Clay- loom \\
Chemical analysis & \\
Soluble ions (meq/l) & \\
$\mathrm{Na}^{+}$ & 2.30 \\
$\mathrm{~K}^{+}$ & 0.70 \\
$\mathrm{Ca}^{++}$ & 1.28 \\
$\mathrm{Mg}^{++}$ & 0.89 \\
$\mathrm{Cl}^{-}$ & 0.90 \\
$\mathrm{HCO}_{3}^{-}$ & 2.00 \\
$\mathrm{SO}_{4}^{--}$ & 2.20 \\
$\mathrm{Available}^{-}$ & \\
$\mathrm{NH}_{4}-\mathrm{N}$ & 610 \\
$\mathrm{NO}_{3}-\mathrm{N}$ & 255 \\
\hline
\end{tabular}

The experiment included 18 treatments which were as follows:

A. Nitrogen sources:

1- Mineral nitrogen fertilizer at $100 \%$ of the recommended dose $(90 \mathrm{~kg}$ $\mathrm{N} / \mathrm{fed}$ ) as ammonium sulphate. 
Table 2: Chemical analysis of the used organic manure(Biogas manure).

\begin{tabular}{lcc}
\hline Characters & \multicolumn{2}{c}{ Seasons } \\
\cline { 2 - 3 } & $\mathbf{2 0 0 7 / 2 0 0 8}$ & $\mathbf{2 0 0 8 / 2 0 0 9}$ \\
\hline Density kg /m & 283.00 & 285.00 \\
Moisture (\%) & 9.15 & 9.20 \\
Organic matter (\%) & 60.80 & 59.20 \\
Organic carbon $(\%)$ & 36.00 & 37.32 \\
Total N (\%) & 1.50 & 1.40 \\
Total P (\%) & 0.80 & 0.75 \\
Total K (\%) & 1.20 & 1.00 \\
C/N ratio & 24.00 & 26.66 \\
\hline
\end{tabular}

Table 3: The quantity of organic and inorganic fertilizers needed to form the total $\mathrm{N}$-fertilizer as $90 \mathrm{~kg} / \mathrm{fed}$.

\begin{tabular}{rcc|ccc}
\hline \multicolumn{3}{c|}{ Inorganic fertilizer } & \multicolumn{3}{c}{ Organic fertilizer } \\
\hline $\begin{array}{l}\text { N-rate } \\
(\mathrm{kg} / \mathrm{fed})\end{array}$ & $\begin{array}{c}\text { Kind of } \\
\text { fertilizer }\end{array}$ & $\begin{array}{c}\text { Fertilizer } \\
(\mathrm{kg} / \mathrm{fed})\end{array}$ & $\begin{array}{l}\text { N-rate } \\
(\mathrm{kg} / \mathrm{fed})\end{array}$ & \multicolumn{2}{c}{$\begin{array}{c}\text { Biogas manure } \\
(\mathrm{kg} / \mathrm{fed})\end{array}$} \\
\hline \multicolumn{1}{c}{} & Ammonium sulphate & 439.0 & 90 & 6000 & 6428 \\
\hline
\end{tabular}

2-Organic fertilizer as biogas manure applied at $100 \%$ of the recommended dose of $\mathrm{N}$ (90 kg N/fed) equal (6000 and $6428 \mathrm{~kg}$ biogas manure/fed during the first and second season, respectively).

$3-50 \%$ of the recommended dose as mineral- $\mathrm{N}+50 \%$ of the recommended dose as organic nitrogen equal ( 3000 and $3214 \mathrm{~kg}$ biogas manure/fed during the first and second season, respectively).

\section{B. Potassium fertilizers:}

1- $48 \mathrm{~kg} \mathrm{~K}_{2} \mathrm{O} / \mathrm{fed}$ as soil application (the recommended dose).

2- $24 \mathrm{~kg} \mathrm{~K}_{2} \mathrm{O} /$ fed as soil application

$3-1 \%$ potassium oxide $\left(36.5 \% \mathrm{~K}_{2} \mathrm{O}\right)$ as foliar application.

4- $2 \%$ potassium oxide $\left(36.5 \% \mathrm{~K}_{2} \mathrm{O}\right)$ as foliar application.

5- $24 \mathrm{~kg} \mathrm{~K} \mathrm{~K}_{2} \mathrm{O} /$ fed soil application plus spray with $1 \%$ potassium oxide.

6- $24 \mathrm{~kg} \mathrm{~K} \mathrm{~K}_{2} \mathrm{O} / \mathrm{fed}$ soil application plus spray with $2 \%$ potassium oxide.

Treatments were arranged in a split plot design with three replicates, where nitrogen sources were assigned in the main plots and potassium fertilizers treatments in the sub plots.

Onion seedlings were transplanted on December $21^{\text {st }}$ and $25^{\text {th }}$ during the first and second season, respectively. Each experimental unit area was $9.8 \mathrm{~m}^{2}$, which contained five ridges with $3.5 \mathrm{~m}$ length and $70 \mathrm{~cm}$ in width. The 
distance between plants was $10 \mathrm{~cm}$ on the two sides of the ridge. Four ridges were planted and one was left without planting as a guard one between plots.

Biogas manure was obtained from station residual managements at Moshtohor, Soil and Water Research Institute, Agriculture Research Center, Ministry of Agriculture. Biogas manure was added to the soil and left two weeks before transplanting.

The mineral nitrogen and potassium fertilizer rates were split and applied to the soil 30 and 60 days after transplanting. Foliar application of potassium treatments started 60 days after transplanting, for three times with 15 days interval. All the experimental plots were received phosphorous fertilizer at the recommended dose $45 \mathrm{~kg} \mathrm{P}_{2} \mathrm{O}_{5} /$ fed as calcium superphosphate fertilizer. P-fertilizer was added once before transplanting at soil preparation. Other agricultural practices were carried out as commonly followed in the district.

\section{Data recorded:}

\section{A. Vegetative growth characteristics:} Morphological characters:

A random sample of ten plants from each experimental plot was taken at 100 days after transplanting in both seasons of study to measure the vegetative growth aspects, i.e. plant height, number of leaves, fresh and dry weight of leaves, bulb and plant as well as diameter of neck and bulb. Bulbing ratio was calculated by using the following formula described by Mann(1952) .

$$
\text { Bulbing rate }=\text { Maximum neck diameter }
$$

\section{B-Plant nutritional status:}

The contents of nitrogen, phosphorus and potassium were assayed in the dry matter of leaves and bulbs according to the methods advanced by Bremner and Mulvaney (1982), Olsen and Sommers (1982) as well as Jackson (1970) for N, P and K, respectively.

\section{C- Yield and its components:}

Plants were harvested when $75 \%$ of plant tops were down and bulbs were weighed and the following data were recorded:

Bulb grades, namely grade 1 ( bulbs with diameter more than $6 \mathrm{~cm}$ ), grade 2 (bulbs with diameter between 4.5-6 cm), grade 3 ( bulbs with diameter between 3.5-4.5 cm) and grade 4 (bulbs with diameter less than $3.5 \mathrm{~cm}$ ). These grades were recorded according to specification laid down by the Ministry of Economic for onion exportation. After that, number and weight of each grade were separately done in the same time, the following data were recorded: 
1- Average bulb fresh weight $=$

Weight of bulbs / plot

\author{
Total number of bulbs /plot
}

2- Exportable yield (grade $1+$ grade 2 ) ton/fed.

3 - Marketable yield (grade $1+$ grade $2+$ grade 3 ) ton/fed.

4 - Total yield (grade $1+$ grade $2+$ grade $3+$ grade 4 ) ton/fed.

\title{
D. Nutritional value of bulbs:
}

1- N, P and K content: At harvest time five bulbs were randomly taken from each treatment and oven dried at $70{ }^{\circ} \mathrm{C}$ till constant weight and the contents of $\mathrm{N}, \mathrm{P}$ and $\mathrm{K}$ were determined by the same methods as previously mentioned in the nutritional status of onion plants.

2- Total soluble solids (T.S.S.): It was determined in fresh bulbs by using Carl Zeis Refractmeter.

\section{Statistical analysis:}

All collected data were subjected to statistical analysis of variance according to Gomez and Gomez (1984) to show the least significant differences between treatments.

\section{RESULTS AND DISCUSSION}

\section{A-Vegetative growth characteristics:}

\section{1- Effect of nitrogen sources:}

Data presented in Tables 4 and 5 show mostly significant differences between the application of ammonium sulphate, biogas manure and their combination for all studied growth aspects, i.e., plant height, number of leaves / plant, fresh and dry weight of leaves and bulb/plant as well as total fresh and dry weight / plant, both neck and bulb diameter, as well as, bulbing ratio in the two growing seasons. In addition, the maximum

values in these traits were achieved by using nitrogen as $50 \%$ mineral-N plus $50 \%$ organic-N compared to the other tested treatments. However, addition of nitrogen as organic manure only significantly reduced all the studied growth parameters. In this regard such increments in growth parameters due to application of nitrogen in the form of $50 \%$ mineral nitrogen and $50 \%$ organic nitrogen may be due to increasing root surface per unit of soil volume as a result of adding organic manure and ammonium sulphate fertilizers. In addition, organic manure contains humic substances which improve physical and chemical properties of the soil and releases nutrients such as $\mathrm{N}$ in the soil and hence increasing the availability to plant grow. Moreover, application of biogas manure increased organic matter 
content incorporated high-levels of organic carbon and nitrogen in the soil and this led to increase plant growth.

In this connection, Marschner (1995) concluded that nitrogen is an indispensable elementary constituent of numerous organic compounds of general importance (amino acids, protein and nucleic acids) and its needed in formation of protoplasm and new cells, as well as its encourage cell elongation.

Obtained results are in harmony with those reported by Mahmoud (2006), Fekry and Abou El-Salehein (2010), Ibraheim (2010), Abd El-Samad et al. (2011)and Abdissa et al. (2011) all working on onion.

\section{2- Effect of potassium fertilization:}

The results in Tables 4 and 5 indicate that there were significant differences among the different tested treatments on all studied growth characters. In this respect such data reveal that application of potassium at 24 $\mathrm{kg} \mathrm{K}_{2} \mathrm{O}$ / fed as soil addition plus spraying the plants with potassium oxide three times at $2 \%$ concentration during the two growing seasons reflected the highest values in all studied growth traits. In addition application of potassium at $100 \%$ of recommended dose ( $48 \mathrm{~kg} \mathrm{~K} 2 \mathrm{O} / \mathrm{fed}$ ) ranks the second treatment followed by application of potassium at half recommended dose $\left(24 \mathrm{~kg} \mathrm{~K} \mathrm{~K}_{2} \mathrm{O} / \mathrm{fed}\right.$ combined with spraying the plants with potassium oxide at $1 \%$.

On the other hand, either the treatments $1 \%$ potassium oxide as foliar application or $24 \mathrm{~kg} \mathrm{~K}$ O/fed as soil application each alone gave the lowest values in this respect. These results are going in the same trend in the two investigated seasons. The superiority of plant growth as a result of potassium application might be attributed to that, potassium is an essential element for plant growth and reproduction. Usually, it is present in plants in quantities larger than any of the other nutrients except nitrogen. It plays many important regulatory roles in biochemical and physiological functions of plant growth, although it does not become a part of the chemical structure of plant (Marschner, 1995).Moreover, the promoting effect of the foliar fertilizer may be due to its role for over come of the problems which prevents the onion plants from using sufficient amounts of potassium to obtain high productivity, such as more $\mathrm{K}$ application in soil may be changing into fixing form which not available for plant absorption (Alexander, 1986 and Franke, 1986). Obtained results are in accordance with those reported by El-Bassiony (2006), El-Desuki et al.(2006), Ghoname et al.(2007) and Abou El-Salehein et al. (2008) on onion ,who found that the correlation within different kinds of potassium fertilizers, application methods and plant growth criteria was positive.

\section{3- Effect of the interaction between nitrogen and potassium fertilization:}

It is obvious from the same data in Tables 4 and 5 that both of studying factors significantly influenced most of the growth traits of onion plants, except 
the plant height, neck diameter and bulbing ratio in both seasons and bulb diameter in the second season only. In general, plants received $50 \%$ mineral $-\mathrm{N}$ $+50 \%$ organic- $\mathrm{N}$ with $24 \mathrm{~kg} \mathrm{~K}_{2} \mathrm{O} /$ fed as soil addition combined with spraying the plants with $2 \%$ potassium oxide gave the highest values of all plant growth criteria , followed by the treatment of $100 \%$ mineral-N combined with the same treatment of potassium fertilization. These results held true in the two growing seasons.

\section{B- Plant nutritional status:}

\section{1- Effect of nitrogen sources:}

It is quite clear from data in Tables 6 and 7 that $\mathrm{N}, \mathrm{P}$ and $\mathrm{K}$ percentages in different plant organs (leaves and bulb) of onion plant were significantly affected by nitrogen application in the form of mineral or organic nitrogen or their mixture at $100 \%$ of the recommended dose. In this respect, the highest values were recorded by using nitrogen in the form of $50 \%$ mineral- $\mathrm{N}$ plus50 $\%$ organic- $\mathrm{N}$ followed by the treatment of $100 \%$ mineral $-\mathrm{N}(90 \mathrm{~kg}$ $\mathrm{N} / \mathrm{fed}$ ).Obtained results were true in both growing seasons.

In this respect organic fertilizers improved the growth and chemical composition of the plant and this might be due to the effective positive role of it on the properties of soil leading to provide the plants with nutrient elements, i.e., micro and macro elements which are essential to plant. Also it serves as a good natural soil texture and conditioner being rich in organic matter ( Ali et al., 2001). On decomposition of the organic matter , carbon dioxide is set free and this may be an indirect way for releasing some of the mineral elements in the soil and that may contributed in building metabolites leading to increase in dry matter accumulation (El-Mansi et al.,2004).

Generally, the superiority of the above mentioned treatments on the nutritional status of onion plants might be due to their stimulating effect on plant growth rate and dry matter accumulation (as shown in Tables 4 and 5) which in turn increased each of $\mathrm{N}, \mathrm{P}$ and $\mathrm{K}$ concentrations.

The obtained results are in agreement with those reported by Mahmoud (2006) and Ibraheim (2010), who found that N, P and K percentage of onion leaves and bulbs were significantly increased by the application of organic manure and ammonium sulphate and their combination.

\section{2- Effect of potassium fertilization:}

It was evident from data presented in Tables 6 and 7 that all potassium fertilization treatments significantly increased $\mathrm{N}, \mathrm{P}$ and $\mathrm{K}$ percentage of onion leaves and bulbs. In addition, application of $24 \mathrm{~kg} \mathrm{~K}_{2} \mathrm{O}$ / fed as soil application plus $2 \%$ of potassium oxide as foliar application being the most effective treatment for increasing $\mathrm{N}, \mathrm{P}$ and $\mathrm{K}$ contents of both leaves and bulbs followed by using $48 \mathrm{~kg} \mathrm{~K}_{2} \mathrm{O} / \mathrm{fed}$ as soil application. On the contrary, the lowest values 
in this respect were more distinct when onion plants were solely fertilized by either $1 \%$ potassium oxide as foliar application or $24 \mathrm{~kg} \mathrm{~K}_{2} \mathrm{O} / \mathrm{fed}$ as soil application.

The enhancing effect of potassium fertilization in this concern may be due to the available $\mathrm{K}$ in soil and/or the high absorbing efficiency of roots (Mengel and Kirkby, 1978). These results are in agreement with those obtained by El-Beheidi et al. (2004), El-Desuki et al. (2006), Abou El-Salehein et al. (2008) and Ibraheim (2010).

\section{3- Effect of the interaction between nitrogen and potassium fertilization:}

Data tabulated in Tables 6 and 7 show that N, P and K percentage in both leaves and bulbs of onion were significantly affected in most treatments except $\mathrm{P}$ percentage of the bulb in the first season and $\mathrm{N}$ percentage of bulb in the second one. In this regard, the highest values of $\mathrm{N}, \mathrm{P}$ and $\mathrm{K}$ percentage were achieved by using $24 \mathrm{~kg} \mathrm{~K} 2 \mathrm{O} /$ fed as soil application plus spraying the plants with $2 \%$ potassium oxide combined with fertilizing the plants by $50 \%$ mineral-N plus $50 \%$ organic $-\mathrm{N}$. On the other hand, the lowest values were obtained by treatment $1 \%$ potassium oxide as foliar application combined with $100 \%$ organic-N.

\section{C - Yield and its components:}

\section{1- Effect of nitrogen sources:}

Data in Tables 8 and 9 indicate that application of different N-sources (organic or mineral) and their combination exerted a marked significant effect on average bulb weight, weight bulbs for grade 1,2,3 and 4 as well as of exportable, marketable and total bulb yield. Moreover, the treatment of $50 \%$ mineral-N $+50 \%$ organic-N was the most effective and favorable treatment for increasing bulbs for grade 1 and 2 as considered as exportable, marketable (grade 1,2 and 3), total bulb yield (grade 1,2,3,and4) and the average bulb weight followed by application of $100 \%$ mineral-N which came in the second rank in this respect. In addition application of $100 \%$ organic $-\mathrm{N}$ increased both grade 3 and 4 compared to the other treatments. These results were held true in the two growing seasons.

From the above mentioned results, it could be suggested that, the application of organic manure (i.e., biogas) alone or combined with inorganic $\mathrm{N}$-fertilizer (i.e., ammonium sulphate) being more favorable and enhanced plant growth, dry weight of different plant parts, high content of minerals and this in turn increased average bulb weight which markedly increased total yield of onion per feddan, whereas, yield can be considered as the final resultant of all physiological processes included growth rate and nutrients uptake. 
The obtained results are in agreement with those reported by Mahmoud (2006), Abou El-Salehein et al. (2008), Hafiz and Mahmoud (2008), Fekry and Abou El-Salehein (2010) and Ibraheim (2010).

\section{2- Effect of potassium fertilization:}

Data recorded in Tables 8 and 9 show that all treatments of potassium fertilization used had significant effect on bulb yield and its components. With regard to different onion bulb grades, it is obvious

from such data that, $24 \mathrm{~kg} \mathrm{~K} \mathrm{~K}_{2} \mathrm{O} /$ fed as soil application plus $2 \%$ of potassium oxide as foliar application significantly increased the yield of grade 1, but the highest value of grade 2 of onion bulbs was recorded by spraying plants with $2 \%$ potassium oxide, meanwhile the lowest yield in this respect was exhibited by the treatment $1 \%$ of potassium oxide as foliar application only.

Furthermore, the treatment $24 \mathrm{~kg} \mathrm{~K} 2 \mathrm{O} / \mathrm{fed}$ soil application plus $2 \%$ potassium oxide as foliar application resulted in corresponding increase in average bulb weight, exportable, marketable and total yield of onion bulbs, followed by the treatment $48 \mathrm{~kg} \mathrm{~K}_{2} \mathrm{O} / \mathrm{fed}$ as soil application which being the second one. These results were true in the two growing seasons.

The enhancement in bulb yield and its components due to K-application may be attributed to the effect of it on the translocation of carbohydrates and other metabolities from leaves to be accumulated in bulb (Mengel and Kirkby, 1978).

These findings are in accordance with that obtained by El-Bassiony (2006), Ghoname et al. (2007) and Abd El -Al et al. (2010) on onion and ElMorsy et al. (2004) on garlic.

\section{3- Effect of the interaction between nitrogen and potassium fertilization:}

The results in Tables 8 and 9 show significant differences among the different interaction treatments in most measurements of total yield and its components. With regard to the bulb grades, the interaction treatments reflect mostly significant effects on onion bulbs weight .

Obtained data show that using nitrogen in the form of $50 \%$ mineral-N plus $50 \%$ organic-N combined with soil addition of potassium rate at $24 \mathrm{~kg} \mathrm{~K}_{2} \mathrm{O} / \mathrm{fed}$ and spraying the plants with $2 \%$ potassium oxide gave the highest onion bulb weight of grade 1 in the two growing seasons. Meanwhile, the treatment of $100 \%$ mineral- $\mathrm{N}$ with $24 \mathrm{~kg} \mathrm{~K} \mathrm{~K}_{2} \mathrm{O} / \mathrm{fed}$ as soil application plus $1 \%$ potassium oxide as foliar application significantly increased onion bulb yield as grade 2 during both growing seasons. Whereas, yield of grade 3 was significantly increased by the interaction between $100 \%$ organic-N combined with using $1 \%$ potassium oxide as foliar application through the two growing seasons. In addition, all the interaction treatments did not reflect any significant effect on onion bulb yield of grade 4 in the first season. On the contrary, grade 4 
recorded the maximum bulbs weight by the interaction between $100 \%$ organic$\mathrm{N}$ combined with using $+1 \%$ potassium oxide as foliar application in both growing seasons . Moreover, it is quite clear from such data in Tables 8 and 9 that, all the interaction treatments reflected insignificant effect on exportable (except the first season), marketable and total onion bulbs yield (ton/fed) in the two growing seasons. Whereas, the maximum values for average bulb weight were recorded by the combination between nitrogen in the form of $50 \%$ mineral-N $+50 \%$ organic- $\mathrm{N}$ combined with $24 \mathrm{~kg} \mathrm{~K}_{2} \mathrm{O} /$ fed as soil application plus spraying plants with $2 \%$ potassium oxide.

\section{D- Nutritional value of bulb}

\section{1- Effect of nitrogen sources:}

Data in Table 10 indicate that addition of nitrogen either as organic (biogas manure) or inorganic (ammonium sulphate) forms and their mixtures gave significant increases in N, P and K concentrations as well as total soluble solids (T.S.S.) in onion bulbs. The highest values of macro-elements content and T.S.S. percentage were obtained from the treatment received nitrogen as $50 \%$ mineral- $\mathrm{N}+50 \%$ organic- $\mathrm{N}$.

These results were true in both seasons of study for N,P and K contents and the second season only for T.S.S. percentage. The favourable effect of biogas manure on the mineral content of bulbs may be attributed to that it was a slow release source for macro-nutrient available for plant uptake along the growing season and in turn increased uptake and accumulation of $\mathrm{N}, \mathrm{P}$ and $\mathrm{K}$ in storage parts (bulbs) of onion (Ranganna et al., 1991). Regarding the nitrogen effect, Mengle and Kirkby (1978) noticed that N, P, K contents were correlated with the uptake of nutrients and dry matter accumulation in different parts of onion plants which fluctuated depending on NPK fertilizers rate, rate of growth and stage of growth. Therefore, $\mathrm{N}$-addition with the highest rate positively affected NPK content in leaves and bulbs. This may be due to increasing the vegetative growth and consequently increased NPK absorption and accumulation in plant tissues.

Such results coincides with those obtained by Mahmoud et al.(2000), Mahmoud (2006), Moursy et al. (2007), Fekry and Abou El-Salehein (2010) and Abd El-Samad et al. (2011) on onion and El-Zohery (2003) on garlic.

\section{2- Effect of potassium fertilization:}

Data in Table 10 show that all treatments of potassium fertilization had a significant effect on N, P, K and T.S. S. percentages in onion bulb. The highest values in this respect were achieved by using the soil application of $24 \mathrm{~kg} \mathrm{~K}_{2} \mathrm{O} /$ fed $+2 \%$ potassium oxide as foliar application compared with $48 \mathrm{~kg} \mathrm{~K}_{2} \mathrm{O} /$ fed (the recommended dose) as soil application or the other treatments in both seasons. 
As regard to the potassium effect, potassium is highly mobile within plant tissues. It moves readily from the lower to the upper and younger plant tissues. Also, potassium has a major role in plant metabolism as it activates enzymes especially in the metabolism of carbohydrates. In addition, it plays a potential role in the transport of water and essential nutrient through the plant in the xylem.

These results are in harmony with those reported by El-Bassiony (2006), Ghoname et al. (2007) and Abd El- Al et al. (2010) and Ibraheim (2010) all working on onion.

\section{3- Effect of the interaction between nitrogen and potassium fertilization:}

Table 10 show clearly that the contents of $\mathrm{N}, \mathrm{P}$ and $\mathrm{K}$ in onion bulbs were influenced significantly by different nitrogen fertilizers and potassium treatments. The best values of the previous nutritional elements were obtained with onion plants received $50 \%$ mineral- $\mathrm{N}+50 \%$ organic- $\mathrm{N}$ combined with 24 $\mathrm{kg} \mathrm{K}_{2} \mathrm{O} / \mathrm{fed}$ as soil application $+2 \%$ potassium oxide as foliar application during both the growing seasons. On the other hand, the interaction treatments did not reflect any significant effects on the percentage of total soluble solids (T.S.S.) in onion bulbs.

Conclusively, it could be concluded that using 50\% mineral-N $+50 \%$ organic- $\mathrm{N}$ in combination with $24 \mathrm{~kg} \mathrm{~K}_{2} \mathrm{O} /$ fed as soil application $+2 \%$ potassium oxide as foliar spray proved to be the most effective treatment to obtain vigor plant growth, highest total, exportable (grade 1 and 2)and marketable(grade 1,2and 3) of yield /feddan and the best quality of onion bulbs as well as lowering cost production and it may be a way to reduce the environmental pollution.

\section{REFERENCES}

Abd El-Al, Faten S., A.M. Shaheen, Rizk, Fatma A. and Hafez, Magda M. 2010. Influence of irrigation intervals and potassium fertilization on productivity and quality of onion plants. International Journal of Academic Research, 2(1): 110-116.

Abd El-Samad, E. H., R. Kh. M. Khalifa, Z.A. Lashine and M. R. Shafeek. 2011. Influence of urea fertilization and foliar application of some micronutrients on growth, yield and bulb quality of onion. Australian Journal of Basic and Applied Sciences, 5(5): 96-103.

Abdissa, Y.,T. Tekalign and L. M. Pant. 2011. Growth, bulb yield and quality of onion (Allium cepa L.) as influenced by nitrogen and phosphorous fertilization on vertisol. 1. Growth attributes, biomass production and bulb yield. African J. Agric. Res., 6 (14): 3252-3258. 
Abou El-Salehein, E.H., A. I. Sharaf and E. E. Abd El-Moula. 2008. Effect of organic manure and potassium fertilization on growth, chemical composition and yield of onion (Allium cepa L.). J. Product. \& Dev., 13(3) : $545-562$.

Alexander, A. 1986. Foliar fertilization. ed. By Alexander. Schering Agrochemical Division, Special fertilizer group, Berlin (FRG), P. 1760.

Ali, A. H., M. M. Abdel-Mouty and A. M. Shaheen. 2001. Effect of bionitrogen, organic and inorganic fertilizer on the productivity of garlic (Allium sativum L) plants. Egypt. J. Appl. Sci., 16(3): 173-188.

A.O.A.C. 1990. Association of Official Agricultural Chemists. Official Methods of Analytical $15^{\text {th }}$ ed. Washington, D.C.USA.

Black, C.A. 1982. Methods of Soil Analysis. Part 2. American Society of Agronomy, INC., publisher, Madison, Wisconsin, USA.

Brady, N.C. and R.R. Weil.1990. The Nature And Properties Of Soils. $9^{\text {th }}$ Edition. Macmillan Publishing Company New York. pp 750.

Bremner, J.M. and C.S. Mulvaney. 1982. Total Nitrogen In: Page, A.L., R.H. Miller and D. R. Keeney (Eds). Methods of Soil Analysis. Part 2, Amer. Soc. Agron. Madison, W. I. USA, pp. 595-624.

Devlin, M. 1969. Plant Physiology. 2Ed. Van Nortrand Reinhold Co. pp 433.

El- Bassiony, A. M. 2006. Effect of potassium fertilization on growth, yield and quality of onion plants. J. Appl. Sci. Res., 2 (10): 780-785.

El-Beheidi, M. A., M. A.I. Khalil, H.E. Arisha and Sabreen, Kh. A. Ibraheim. 2004. Onion crop response to nitrogen and potassium fertigation and soil application. Zagazig J. Agric. Res., 31 (5): 21232138.

El-Desuki, M., M. M. Abdel-Mouty and A. H. Ali. 2006. Response of onion plants to additional dose of potassium application. J. Appl. Sci. Res., 2(9):592-597.

El-Mansi, A.A., A. Bardisi, A. N. Fayad and E.E. Abou El-Khair. 2004. Effect of water quality and farmyard manure on garlic under sandy soil conditions.2- Yield and its components, water use efficiency and bulb quality. Zagazig J. Agric. Res., 31 (4A): 1385-1408.

El-Morsy, A. H. A., Z.S. El-Shal and Sawsan, M.H. Sarg. 2004. Effect of potassium application methods and some micronutrients on growth, yield and storability of garlic. J. Agric. Sci. Mansoura Univ., 29(4): 2103-2023.

El-Oksh, I.I., M.E. Ragab, A.A. Abd El-Halim and S. A. Barakat. 2002. Response of onion to some fertilization and irrigation treatments. 1Yield and its components. $2^{\text {nd }}$ Inter. Conf.Hort. Sci., 10-12 Sept. kafr El-Sheikh, Tanta Univ., Egypt. 
El-Zohery, S.S.M. 2003. Physiological studies on garlic crop. Ph D. Thesis, Faculty of Agriculture, Moshtohor, Zagazig University, Benha Branch. 160 pp. Egypt.

Fekry, Wafaa, A. and E.H. Abou El-Salehein. 2010. Influence of different sources of fertilizers and yeast on growth, chemical composition, yield and its quality of onion plants. J. Product. \& Dev., 15 (3): 405-422.

Franke, W. 1986. The basis of foliar absorption of fertilizers with special regard to the mechanism. "Foliar Fertilization" Ed. by Alexander. Schering Agrochemical Division, Special Fertilizer group, Berlin (FRG), P. 17-25.

Ghoname, A. , Z.F.Fawzy, A.M. El-Bassiony, G. S. Riadand and M.M.H. Abd El-Baky. 2007. Reducing onion bulbs flaking and increasing bulb yield and quality by potassium and calcium application. Australian Journal of Basic and Applied Sciences, 1 (4): 610-618.

Gomez, K. A. and A. A. Gomez. 1984. Statistical Procedures for Agricultural Research. $2^{\text {nd }}$ ed., John Wiely \& Sons. New York.

Graham, E.R.and P.L. Lopez. 1969. Freezing and thawing as a factor in the release and fixation of soil potassium as demonstrated by isotopic exchange and calcium exchange equilibria. Soil Sci., 108: 143-147.

Hafiz, Magda, M. and Asmaa, R. Mahmoud . 2008. Response of onion plants to the fertilization by nitrogen sources and agricultural sulphur rates. J. Agric. Sci. Mansoura Univ., 33(7): 5235-5243.

Ibraheim, Sabreen, K. A. 2010. Effect of different fertilizers on yield and nutritional value of onion under sandy soil conditions. Ph. D. Thesis faculty of Agriculture, Zagazig University, pp133.

Jackson, M. L. 1970. Soil chemical Analysis. Prentic Hall, Inc. Englewood Cliffs, New Jeresy, pp 498.

Mahmoud, Hosna, A.F., F.A.A. Sedera and Yousef, Shadia B.D. 2000. Effect of organic and inorganic fertilizers on onion crop. J. Agric. Sci. Mansoura Univ., 25 (9): 5813-5829.

Mahmoud, M. R. 2006. Effect of some organic and inorganic nitrogen fertilizers on onion plants grown on a sandy calcareous soil. Assiut J. of Agric. Sci., 37 (1): 147-159.

Mann, L. K. 1952. Anatomy of garlic bulb and factors affecting bulb development. Hilgardia, 21: 195-231.

Marschner, H. 1995. Mineral Nutrition Of Higher Plant. $2^{\text {nd }}$ ed., Academic Press. Limited. Text Book. pp 864.

Mayer, B.S and O.B. Anderson. 1952. Plant Physiology. Handbook Van Nastrand Co. PP. 784.

Mengel, K. and E. A. Kirkby. 1978. Principles of Plant Nutrition. International Potasch Institute, P.O. Box, CH-3048 Worblaufen-Bern/ Switzerland. 
Moursy, M. El., H. E. Khalifa, M. M. Attia, M. A. Sayed and A. M. Osman. 2007. Effect of organic and nitrogen fertilizers and plant densities on onion production in sandy soil under drip irrigation system. Alex. J. Agric. Res., 52 (1):103-108.

Olsen, S.R. and L.E. Sommers. 1982. Phosphorus. In: Methods of Soil Analysis, Part 2. Amer. Soci. Agron., Madison, W.I.USA, pp. 403-430.

Ranganna, B., S. Y. S. Pillegowda, S. M. Reddy, H. Huliyarappa and A. M. Krishnappa. 1991. Spent sludge- an enriched manure. Current-Res. Univ. of Agric. Sci. Bangalore,1991), 20 (4): 66-67. (C.F. data base of Agricola-Internet)

Tisdale, S.L., W.L. Nelson and J. D. Beaton. 1985. Soil fertility and fertilizers, $4^{\text {th }}$ Ed. Macmillan Publ. Co. New York, pp, 328-334.

\section{استجابة محصول البصل لمصادر النتروجين المختلفة وطرق إضافة

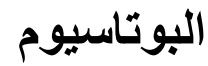






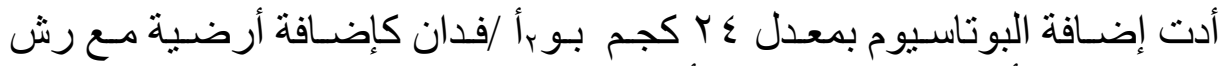

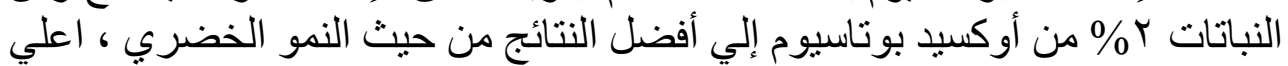

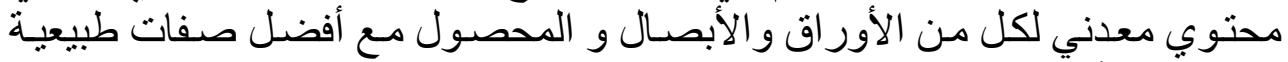

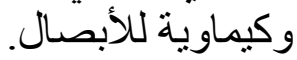

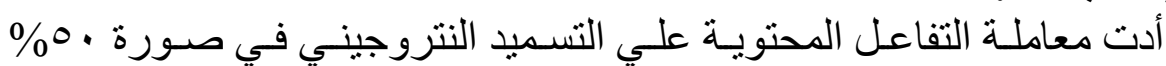

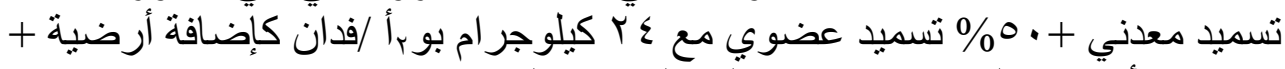

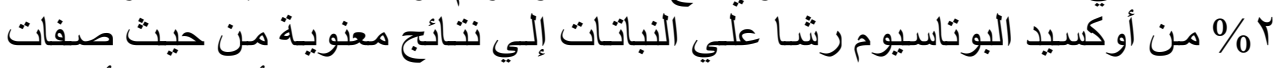

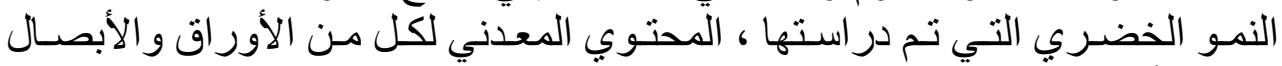

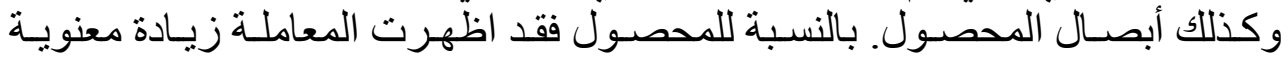

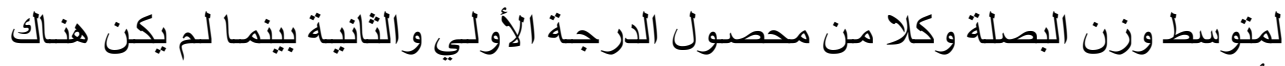

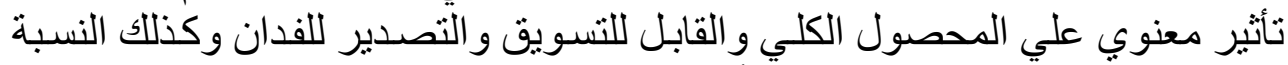
المئوية للمو أدالصلبة الذائبة الكلية للأبصال.

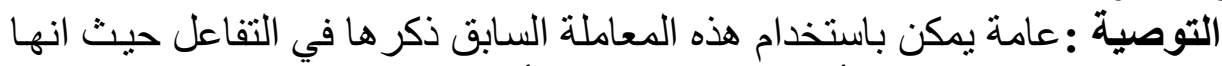

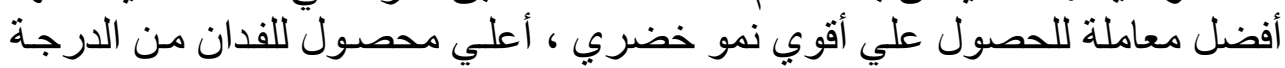

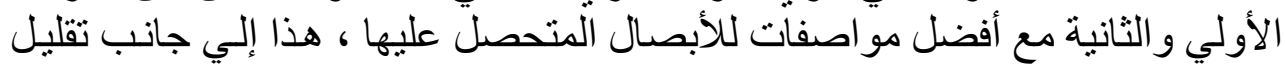
تكاليف الإنتاج وكذلك كوسيلة لتقليل تلوث للابه البيئة. 